\title{
Farmers' perception regarding climate change in Southern Turkey: The case of the Mersin province
}

\author{
Seyit Hayran*, Sinan Duru*, Burcak Kapur** \\ Aykut Gul*, Yavuz SAhIn Turgut***
}

DOI: $10.30682 / \mathrm{nm} 2101 \mathrm{e}$

JEL codes: C23, Q12, Q54

\begin{abstract}
Climate change is responsible for the negative effects on human life causing a decrease in agricultural products availability, biodiversity, soil fertility, and forest areas. Moreover, climate change increases plant diseases and pests, the cost of agricultural production and risk in food security. This study aims to determine whether climate change is a phenomenon via the analysis of the perceptions of the farmers regarding this issue in the Mersin province conducted through 251 questionnaires. Farmers primarily perceive climate change through production costs and the reduction in yield. Moreover, they are highly aware of its relation to natural events such as floods, drought, and storms. Nevertheless, inappropriate agricultural practices too have led to the negative consequences caused by climate change. In this respect, this study has revealed that farmers with strong cooperative partnerships and experience perceived climate change significantly.
\end{abstract}

Keywords: Farmers'perception, Climate change, Mann-Kendall, Sen's Slope

\section{Introduction}

Climate change remains one of the most important environmental threats for both humans and all life forms including plants, animals and other living things worldwide (Nakicenovic et al., 2000). The global average of surface temperature has increased by $0.74{ }^{\circ} \mathrm{C}$ in the last century. This is the highest temperature rise recorded in the last 12 years, according to data dating back to 1850 . More severe and longer droughts have been observed since the 1970s in the midlatitudes (IPCC, 2012). In particular, Turkey, located in the eastern parts of the Med- iterranean Basin, is one of the most vulnerable regions to climate change, as identified by the fourth Assessment Report of the Intergovernmental Panel on Climate Change (IPCC, 2012). In this context, the average air temperature rose by $0.64{ }^{\circ} \mathrm{C}$ and precipitation decreased by 29 mm from 1941 to 2007 in Turkey, where this increase was generally encountered in the annual maximum and minimum temperature series and was statistically significant in the south of the country. Furthermore, significant decreases in precipitation and number of rainy days were also observed especially in the winter mostly along

\footnotetext{
* Department of Agricultural Economics, University of Cukurova, Adana, Turkey.

** Department of Farm Structures and Irrigation, University of Cukurova, Adana, Turkey.

*** Department of Soil Science and Plant Nutrition, University of Cukurova, Adana, Turkey.

Corresponding author: shayran@cu.edu.tr
} 
the Mediterranean coast (IPCC, 2013). Nevertheless, this reveals that the impacts of climate change have become inevitable and should be studied on regional scale.

Consequently, climate change will heavily affect agricultural production systems, and farmers' living conditions and lifestyle (Dellal et al., 2011; Tsujii and Gültekin, 2019). Forecasting the possible effects of climate change on agricultural production and the adoption of appropriate farming techniques by farmers in order to mitigate to negative effects of climate change is vital for the future generation. A great deal of empirical study has measured the effects of climate change on agriculture and the measures to be taken in order to reduce and/or minimize these negative effects in Turkey (Kanber et al., 2008; Dellal et al., 2011; Akyuz and Atis, 2016; Dumrul and Kilicaslan, 2017; Karakas and Dogan, 2018; Bozoglu et al., 2019; Tsujii and Gültekin, 2019). The common conclusions raised in the aforementioned studies are that, depending on climate change, there may be a decrease in the productivity of agricultural products and an increase in the prices. And also, the authors stated that these negative consequences could be mitigated by establishing appropriate policies, strategies, plans, and programs. Some policy recommendations have been developed in these studies to mitigate the negative effects of climate change.

In order to encourage farmers to adopt agricultural practices to mitigate the negative effects of climate change, it is necessary to understand how they perceive climate change and develop appropriate intervention tools. So, As well as to empirical results, policy makers should pay special attention to the perceptions of farmers who implement the measures to be taken to mitigate the effects of climate change. However, the analysis of the farmers' perception of climate change was seen as a deficiency in Turkey. We found only three studies which estimated WTP for the adaptation of agricultural practices to mitigate the effects of climate change in Turkey (Aydogdu and Yenigün, 2016; Öz, 2019; Polat and Dellal, 2016). However, this topic has received great attention in foreign literature in recent years (Akhtar et al., 2018; Hameso, 2017; Lane et al., 2017; Ndamani and Watanabe, 2017). So, the main objectives of this study are to analyze farmers' climate change perception and its determinants in Mersin Province where located in the southern part of Turkey. Furthermore, the MannKendall trend analysis and Sen's slope estimate has been employed to monitor the change in rainfall, average temperature, and relative humidity to provide evidence about the climate change phenomenon in the study area, based on data belonging to the period 1959-2019. Main reason selected of Mersin as the research area is that Dudu and Çakmak (2018) stated that the effects of climate change on the economy will be drastic changes both in agricultural production and commodity prices in Turkey. And also, they reported that climate shocks will severely affect agricultural products and food commodities, but coastal regions will be affected relatively less until the 2060s. So, this may be seen as an advantage for taking precautionary measures to mitigate the adverse effects of climate change in Mersin. In this study, the perceptions of farmers regarding climate change were analyzed and it was confirmed that climate change is a phenomenon in the region under study with meteorological data. This is the difference between this study and other studies conducted in Turkey.

In this study, it was determined that climate change is a real phenomenon in the Mersin based on meteorological data. The understanding of farmers' climate change perception in Mersin Province of Turkey is important. The findings of this study might be useful to develop and implement interventions that are in keeping with farmers' perception to mitigate the negative effect of climate change on agriculture. For example, farmers believe that climate change will cause an increase in agricultural costs. For this reason, economic interventions can be used to face climate change. Also, understanding farmers' perceptions and thoughts on climate change is a key factor to increase the adoption of the best agricultural practices for dealing with climate change. Daly-Hassen et al., (2019) statted that the adoption of the best agricultural practices to mitigate the negative effects of climate change provides benefits from a regional, global, and societal point of view. 
The remainder of the study is organized as follows: Section 2 deals with materials and methods; Section 3 presents a discussion on the results, and Section 4 presents the conclusions.

\section{Materials and methods}

\section{Research Area and field data}

The data used in this study came from the surveys conducted in the Mersin province. A cross-sectional survey method was used in this study during the period of May-August 2019. The research data were collected from 251 randomly selected farmers in Mersin through experienced enumerators (Figure 1). The data collection tool was a structured questionnaire which consisted of two parts. The first section consisted of information on socio-economic characteristics of farmers. The second section was a list of 14 items designed to assess the farmers' climate change perceptions. These were prepared taking into account the previous studies on climate change (Akhtar et al., 2018); Hameso, 2017; Lane et al., 2017; Ndamani and
Watanabe, 2017). The 14 items are presented in Table 2. The reliability of the climate change perception scale was estimated by calculating Cronbach's alpha coefficient (Cronbach, 1951) which amounted to 0.933 .

\section{Data analysis}

In this study, descriptive statistics (mean and standard deviation), multiple linear regression analysis and factor analysis (Principal Component Analysis - PCA) were used. Descriptive statistics such as the mean and standard deviation were used in order to delineate farmers' socio-economics characteristics. And then, Factor analysis (PCA) was applied to the climate change perception scale. Kaiser-Maier-Olkin (KMO) and Bartlett's sphericity test were used to verify the suitability of scale for PCA. The results of KMO (the KMO value was 0.920 ) and the significance of Bartlett's sphericity test ( $p$ value was 0.000 ) confirmed that scale and data suitable for PCA. The number of factors selected was based on the Kaiser's criterion, where only factors with eigenvalues greater than 1.00

Figure 1 - Mersin province.
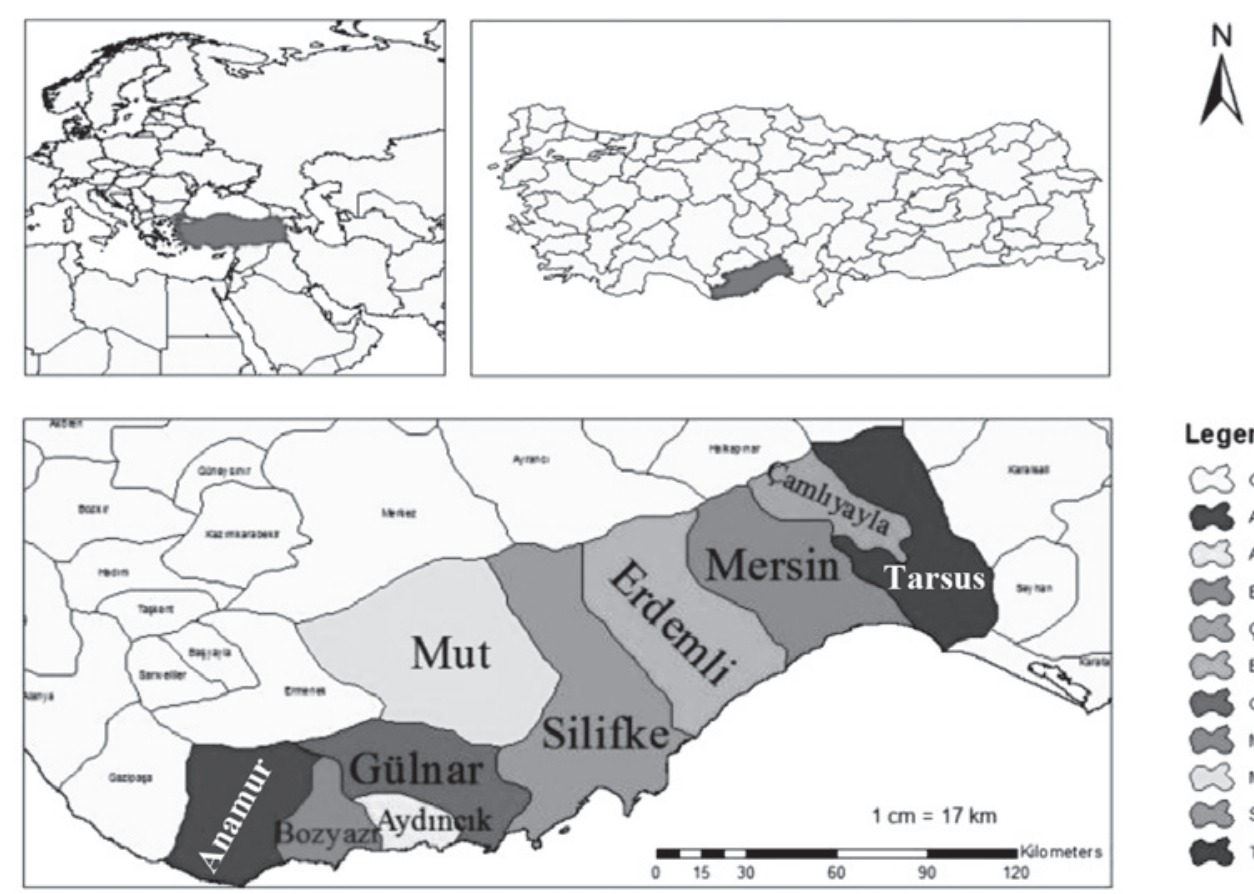

Legend 
were selected. Using factors scores from PCA as dependent variable, a multiple linear regression analysis was used to determine the influence of some socioeconomics variables on the farmers' climate change perceptions (Gujarati, 2009).

\section{Climate data analysis techniques}

Farming activities depend on climate conditions and are at risk via a changing climate (Porter et al., 2014); thus it would be expected that farmers have a long-term point of view on climate because of its direct effect on their welfare (Niles and Mueller, 2016). However, we do not know of any studies that have analyzed the farmers' perception of climate change, tracking observed climate changes at the same time. To that end, we applied a trend analysis in this study area to detect the change of climate parameters on a seasonal basis. Temperature, rainfalls and relative humidity are the most significant variables in the field of climate sciences usually used to detect the magnitude of climate change (IPCC, 2007; Asfaw et al., 2018). Despite the available information on climate trends stored in the archives of the State Meteorological Office of Turkey, there is no definite guidance or research conducted using the data of the Mersin province. Furthermore, some previous studies that did not include the data of the last decades focused on the trends of the surface climatic variables, such as Türkeş et al. (1995), used Mann-Kendall nonparametric test to identify trends in the long-term mean temperature of both individual stations and geographical regions in Turkey during the period 1930-1992. Kadıoglu, (1997), examined trends in the mean annual temperature records during the period 1939-1989 in the eighteen stations across Turkey. Partal and Kahya (2006) detected the trend of rainfall records at 96 stations by using the monthly total precipitation variables from 1929 to 1993 . Thus, in this study the data used consist of the monthly time series of near-surface meteorological variables observed at 4 meteorological stations (Mersin, Erdemli, Silifke, Anamur) from the State Meteorological Office of Turkey, including: the mean air temperature $\left({ }^{\circ} \mathrm{C}\right)$, rainfall $(\mathrm{mm})$ and relative humidity (\%). The major considerations for selecting these stations were the following: spatial distribution of the stations across the region; availability of the longest possible records within the period of 1959-2019, and completeness of the records without missing data points. In accordance with this purpose, we use the most common non-parametric test, which is the Mann-Kendall test, to analyze the time series trends. Moreover, Mann-Kendall test is nonparametric; therefore, data outliers do not affect the results (Ahmad et al., 2015). Therefore, this test determines whether the data trend is upward or downward over time through what is essentially a non-parametric form of monotonic trend regression analysis (Donald et al. 2011).

\section{Mann-Kendall Test}

The Mann-Kendall (MK) non-parametric test has been widely used to assess the significance of trends in meteorological time series (Liang et al., 2010; Topaloğlu and Ozfidaner 2012; Liu et al., 2014). This approach needs a few assumptions on the data to be made, especially concerning their distribution. The Mann-Kendall test is based on the null hypothesis that a sample of data is independent and identically distributed, which means that there is no trend or serial correlation among the data points. The alternative hypothesis is that a trend exists in the data (Novotny and Stefan, 2007). The trend test is applied to the data series $x_{i}$ ranked from $i=1, \ldots, n-1$, and $x_{j}$ is ranked from $j=i+1, \ldots, n$. Each data point $x_{i}$ is used as a reference point and is compared with all other data points $x_{j}$ so that

$$
\operatorname{sgn}\left(x_{j}-x_{i}\right)\left\{\begin{array}{c}
1 \text { for } x_{j}>x_{i} \\
0 \text { for } x_{j}=x_{i} \\
-1 \text { for } x_{j}<x_{i}
\end{array}\right.
$$

The MK test statistic $\mathrm{S}$ is calculated as

$$
\mathrm{S}=\sum_{\mathrm{i}=1}^{\mathrm{n}-1} \sum_{\mathrm{j}=\mathrm{i}+1}^{\mathrm{n}} \operatorname{sgn}\left(\mathrm{x}_{\mathrm{j}}-\mathrm{x}_{\mathrm{i}}\right)
$$

where $\mathrm{n}$ is the length of the data set. The statistic $\mathrm{S}$, when $\mathrm{n} \geq 8$, is approximately normally distributed with the mean and the variance given by

$$
\begin{aligned}
& E[S]=0 \\
& \operatorname{Var}(S)=\frac{n(n-1)(2 n+5)-\sum_{i=1}^{p} t_{i}\left(t_{i}-1\right)\left(2 t_{i}+5\right)}{18}
\end{aligned}
$$

in which $p$ is the number of tied groups in the 
data set, and $t_{i}$ is the number of data points in the $i$ th tied group. The summation term in Eq. (4) is only used if data values are tied in the series. The standardized MK statistic Z is computed by

$$
Z=\left\{\begin{array}{l}
\frac{S-1}{\sqrt{\operatorname{Var}(S)}} \text { for } S>0 \\
0 \text { for } S=0 \\
\frac{S+1}{\sqrt{\operatorname{Var}(S)}} \text { for } S<0
\end{array}\right.
$$

and follows the standard normal distribution with the mean of zero and variance of one under the null hypothesis of no trend in the series. The null hypothesis is rejected if $|\mathrm{Z}| \geq \mathrm{z}_{1-\alpha / 2}$ is at the $\alpha$ level of significance, where $z_{1-\alpha / 2}$ is the (1$\alpha / 2$ ) quantile in the standard normal distribution. A positive $\mathrm{Z}$ value indicates an upward trend, whereas a negative value indicates a downward trend. A significance level of 5\% will be used in the analysis, which means that there is a 5\% uncertainty and, in this respect, it would be correct to reject the null hypothesis that a trend does not exist in the data set.

\section{Sen's Slope Estimate}

Various tests exist and can be employed for the detection and/or quantification of the magnitude of the trend. According to the data time series, if a linear trend is detected, the exact slope could be estimated using an uncomplicated nonparametric method given by Sen (1968). Sen's slope estimator inclines in many cases more toward the trend determination of the robust methods and confirms the trend sign and magnitude estimates by applying the robust parametric methods (Muhlbauer et al., 2009). Moreover, Sen's slope estimator is generally applied on climate parameters, for instance, see Marofi et al. (2012) and Huang et al. (2013). The Sen's slope estimator, by calculating the slope of the line using all data value pairs is deter-mined as follows

$$
\mathrm{Q}_{\mathrm{i}}=\frac{\mathrm{x}_{\mathrm{j}}-\mathrm{x}_{\mathrm{i}}}{\mathrm{j}-\mathrm{k}} \mathrm{i}=1,2, \ldots . \mathrm{N} \text { where } \mathrm{j}>k
$$

If there are $n$ values $x_{j}$ in the time series we get as many as $N=n(n-1) / 2$ slope estimates $Q_{i}$. The Sen's slope estimator is the median of these $\mathrm{N}$ values of $\mathrm{Q}_{\mathrm{i}}$. The $\mathrm{N}$ values of $\mathrm{Q}_{\mathrm{i}}$ are ranked from the smallest to the largest and the Sen's estimator is

$$
Q=\left\{\begin{array}{c}
Q_{\frac{N+1}{2}} \text { if } N \text { is odd } \\
\frac{1}{2}\left(Q_{\frac{N}{2}}+\frac{Q_{N+2}}{2}\right) \text { if } N \text { is even }
\end{array}\right.
$$

\section{Results and Discussion}

\subsection{Trends and the Magnitude of Seasonal Temperature, Rainfall and Relative Humidity Series}

The seasonal mean temperature trend assessment results obtained by the Mann-Kendall test and the magnitude of trend changes of the four meteorological stations in the area under study that were calculated by the nonparametric method of Sen's, are shown in Table 1. Over the period of 1959 to 2019, the Mann-Kendall test confirmed the occurrence of stronger warming trends for the all stations. The significant (14 times) and insignificant upward (2 times) trends were obtained for each seasonal data of the stations. The average warming in the Mersin province in the Mediterranean part of Turkey, was the highest by $2.2^{\circ} \mathrm{C} 61$ years $^{-1}$, in the range 1.5 with $3.2{ }^{\circ} \mathrm{C} 61$ years $^{-1}$ in the summer season and the lowest in winter $\left(1.1^{\circ} \mathrm{C} / 51\right.$ years $)$, whereas the rise of the mean temperatures in the autumn and spring tended to be lower than in the summer. The analysis conducted by Türkeş et al. (2002), on the dataset of the Turkish mean temperature series of 70 stations with 9 stations located in the Mediterranean region, revealed increasing trends from 1942 to 1999 coinciding with our results. Moreover, Türkeş et al. (2002) determined a warming trend of approximately $0.25{ }^{\circ} \mathrm{C}$ decade $^{-1}$ in the summer for the Mediterranean region, whereas ours is $0.36{ }^{\circ} \mathrm{C}$ decade $^{-1}$. The reason for this could be the different ending period of the data used for which many studies have proven that a change in temperatures has occurred near the 2000s. Moreno et al. (2016) introduced that most of the observed warming was due to changes after the year 2000s. The radiative forcing of the climate system has continued to rise during the 2000 s, as it was related to the increase in greenhouse gases (IPCC, 
2014). Thus, changes in radiative forcing evokes increased warming at the surface (Trenberth, 2011), and this could be the reason for the enhanced warming. In addition to this, the overall annual mean temperature analysis in the area under study revealed a dramatic increase of 1.67 ${ }^{\circ} \mathrm{C}$ over the past 61 years. On the other hand, the differences in the trend rates between the stations could mainly be explained by the urbanization level. Stronger warming trends of annual minimum temperatures are mostly observed in the stations that are rapidly urbanizing or which are already urbanized cities, as in the summer (Türkeş et al., 2002). According to our results, the Mersin station has the strongest increase in temperature which is related to higher urbanization compared to the others. In this sense, exposure to increased temperatures causes faster crop development which reduces production and also has negative impacts during the reproductive stage of crop development (Hatfield et al., 2011). Higher temperatures also increase the evapotranspiration demand for crops and thus cause greater water stress. Thus, surveying is needed in regions like Mersin to determin the perceptions of the farmers on climate change.

A nonuniform difference in the trend of the total seasonal precipitations was determined among the meteorological stations (Table 1). The insignificant downward (9 times) and insignificant upward (7 times) trends were obtained for each seasonal data of the stations. Thus, the results of the analysis documented decreasing trends that were determined to be almost insignificant for all seasons. The highest number of insignificant decreasing trends were obtained for winter (4 times over 4$)$, then for spring (2 times) and autumn (2 times), with the average decrease of $83 \mathrm{~mm} 61$ years $^{-1}, 13 \mathrm{~mm} 61$ years $^{-1}$, increase of $13 \mathrm{~mm} 61$ years $^{-1}$ respectively. Approximately, no changes have been detected for the summer during the last 61 years from the monitored

Table 1 - The results of the MK and Sen's slope estimates for seasonal mean temperature, rainfall and relative humidity.

\begin{tabular}{|c|c|c|c|c|c|}
\hline \multirow[t]{2}{*}{$\begin{array}{l}\text { Meteorological } \\
\text { Station }\end{array}$} & \multirow{2}{*}{$\begin{array}{c}\begin{array}{c}\text { Significance } \\
\text { of MK for Seasons }\end{array} \\
\text { A-W-Sp-S }\end{array}$} & \multicolumn{4}{|c|}{$\begin{array}{l}\text { Average Temperature Sen's Slope Estimate } \\
\left({ }^{\circ} \mathrm{C} 60 \text { years }{ }^{-1}\right)\end{array}$} \\
\hline & & $\mathrm{A}$ & W & $\mathrm{Sp}$ & $\mathrm{S}$ \\
\hline Mersin & $\Delta \Delta \Delta \Delta$ & 3.7 & 2.5 & 2.8 & 3.2 \\
\hline Erdemli & $\mathbf{\Delta} \triangle \boldsymbol{\Delta} \boldsymbol{\Delta}$ & 0.8 & 0.2 & 0.8 & 1.5 \\
\hline Silifke & $\mathbf{\Delta} \triangle \boldsymbol{\Delta} \boldsymbol{\Delta}$ & 1.1 & 0.9 & 1.3 & 1.9 \\
\hline \multirow[t]{3}{*}{ Anamur } & $\Delta \mathbf{\Delta} \boldsymbol{\Delta} \Delta \mathbf{\Delta}$ & 2.0 & 0.7 & 1.1 & 2.1 \\
\hline & Average Change & 1.9 & 1.1 & 1.5 & 2.2 \\
\hline & & \multicolumn{4}{|c|}{$\begin{array}{l}\text { Rainfall Sen's Slope Estimate } \\
\text { (mm } 60 \text { years-1) }\end{array}$} \\
\hline Mersin & $\triangle \nabla \triangle \triangle$ & 38 & -46 & 18 & 8 \\
\hline Erdemli & $\nabla \nabla \nabla \nabla$ & -17 & -28 & -35 & -2 \\
\hline Silifke & $\triangle \nabla \triangle \triangle$ & 44 & -77 & 6 & 0.5 \\
\hline \multirow{3}{*}{ Anamur } & $\nabla \nabla \nabla \triangle$ & -14 & -182 & -42 & 0.5 \\
\hline & Average Change & 13 & -83 & -13 & 2 \\
\hline & & \multicolumn{4}{|c|}{$\begin{array}{c}\text { Relative Humidity Sen's Slope Estimate } \\
(\% 60 \text { years- } 1)\end{array}$} \\
\hline Mersin & $\nabla \nabla \nabla \nabla$ & -19.1 & -17.0 & -14.8 & -8.7 \\
\hline Erdemli & $\boldsymbol{\nabla} \nabla \boldsymbol{\nabla} \nabla$ & -7.5 & -4.8 & -5.7 & -4.4 \\
\hline Silifke & $\boldsymbol{\nabla} \nabla \boldsymbol{\nabla} \nabla$ & -8.4 & -5.9 & -6.2 & -4.5 \\
\hline \multirow[t]{2}{*}{ Anamur } & $\nabla \nabla \triangle \triangle$ & -3.8 & -3.8 & 0.7 & 3.6 \\
\hline & Average Change & -9.7 & -7.8 & -6.5 & -3.5 \\
\hline
\end{tabular}

Note: Upward $(\triangle)$ and downward $(\nabla)$ pointing open triangles indicate insignificant increasing and decreasing trends at the 5\% level, respectively. Trends significant at the 5\% level (-1.96 $\geq Z \geq+1.96)$ are marked by solid triangles ( $\mathbf{\Lambda}$ or $\boldsymbol{\nabla})$. W, Winter; Sp, Spring; S, Summer; A, Autumn. 
climate data. Similarly, Tayanç et al. (2009), observed a marked number of insignificant decreases in the station-based precipitations. Annually, the average total rainfall decreased by $81 \mathrm{~mm} 61$ years $^{-1}$ in our study area. Decreasing trends in precipitations were also recorded in some recent climatic studies undertaken in Turkey for the subject area (Fujihara et al., 2008; Diaz and Topçu, 2010). Moreover, similar results were obtained in different parts of Europe, like in Italy, where it was documented that the total precipitations in the 20th century had decreased by about $5 \%$ in the north and by about $15 \%$ in the south of the country (Buffoni et al., 1999; Brunetti et al., 2001).

In addition to all this, the significant downward (9 times) and insignificant downward (5 times) as well as the insignificant upward (1 times) trends were obtained for each season and station reflecting the dominant decreasing of relative humidity trends of the study area (Table 1). The highest decreasing trends were obtained for autumn $(9.5 \%)$ followed by winter $(7.8 \%)$, spring $(6.5 \%)$ and summer $(3.5 \%)$. The results of the current study are in line with the study of Kousari and Zarch (2011), which indicates that there has been a definite decrease in the relative humidity in a range of 2.18 to $6.85 \%$ in Iran from 1955 to 2000 . According to the results of our study, it is clear that there is a negative correlation between relative humidity and air temperature, which was expected.

Consequently, the data reflects that climate is changing in the study area. In particular, the farmers' perception is critical for assisting policy makers in developing proactive precautions within the scope of the fight against climate change.

\subsection{Characteristics of farmers}

Farm size ranged from 0.1 ha to 624 ha, and the average farm size was 7.55 ha in the area under research. $4 \%$ of the total surveyed farmers (n: 10) were female and the other $96 \%$ were male (n: 241). The farmers' ages ranged from 21 years to 87 years and the average age was 48.62 years (SD: 11.18). The average family size of the surveyed farmers was of 4.4 people (SD: 1.33). The education level of the farmers was gener- ally low. $59.80 \%$ of the farmers had attained primary school education, $22.30 \%$ had attained secondary school education, $16.30 \%$ were university graduates and $1.60 \%$ had obtained a master's degree. Farmers' agricultural experiences ranged from 1 year to 75 years and average experience in agriculture was of 26.48 years (SD: 14.83). $43.03 \%$ of farmers (n: 108) had an offfarm income source, but the remaining $56.97 \%$ (n: 143) had not. $41.48 \%$ of the farmers (n: 105) kept physical and financial records of the agricultural production process, but the remaining $58.27 \%$ (n: 146 ) did not. $53.78 \%$ of farmers (n: 135) were supported by extension services about the agricultural production process, but the other $46.22 \%$ (n: 116 ) was not. $33.07 \%$ of farmers (n: 83 ) were a partner of an agricultural cooperative, the remaining $66.93 \%$ (n: 168 ) were not. $68.92 \%$ of farmers (n: 173) did not get a soil analysis, but the other $31.08 \%$ (n: 78$)$ did.

\subsection{Farmers' climate change perceptions}

Farmers' climate change perception investigated using a scale consisted of 14 items. The scores given by the farmers to the items on the scale of climate change perception were over 3.80 . So, it can be said that farmers' perception of climate change was quite strong. Also, the standard deviation of 12 out of 14 items was below 1.00. This indicates that there was a general consensus on farmers' perception of climate change. Factor analysis was used to reduce the items in a smaller number of common factors. Factor analysis exacted 2 factors with eigenvalues greater than 1 . The two factors extracted from factor analysis explained $61.175 \%$ of the total variation. The first factor explained $30.74 \%$ of the total variation and consisted of eight items, and the second factor explained $30.435 \%$ of the total variation and consisted of six items (Table 2).

In the research area, according to the farmers' perception, the most important issues linked to the impact of climate change is the possibility of the increase in agricultural production costs and the possibility of decrease in the yield of cultivated field crops and vegetables. This finding confirmed the finding of Ndamani and Watanabe (2017). As a matter of fact, as a result of climate 
Table 2 - Climate change perception scale's items and the result of factor analysis.

\begin{tabular}{|c|c|c|c|c|}
\hline \multirow{2}{*}{ Items* } & \multicolumn{2}{|c|}{ Component } & \multirow{2}{*}{ Mean } & \multirow{2}{*}{$S D$} \\
\hline & 1 & 2 & & \\
\hline $\mathrm{CC}$ will lead to an increase in agricultural production costs & 0.401 & 0.574 & 4.34 & 0.82 \\
\hline $\begin{array}{l}\mathrm{CC} \text { will cause an increase in weather events such } \\
\text { as droughts, floods, and storms, etc. }\end{array}$ & 0.121 & 0.832 & 4.18 & 0.89 \\
\hline $\mathrm{CC}$ will cause an increase in plant diseases and pests & 0.648 & 0.478 & 4.17 & 0.86 \\
\hline $\begin{array}{l}\text { CC will cause a decrease in the yield of cultivated field } \\
\text { crops and vegetables }\end{array}$ & 0.321 & 0.780 & 4.16 & 0.90 \\
\hline $\mathrm{CC}$ will cause an increase in soil erosion & 0.385 & 0.673 & 4.12 & 0.82 \\
\hline $\begin{array}{l}\mathrm{CC} \text { will lead to a reduction in the amount of agricultural } \\
\text { land }\end{array}$ & 0.560 & 0.551 & 4.09 & 0.92 \\
\hline $\mathrm{CC}$ will adversely affect food security & 0.617 & 0.449 & 4.05 & 0.96 \\
\hline $\begin{array}{l}\mathrm{CC} \text { will cause a decrease in both cultivated and wild } \\
\text { plant species }\end{array}$ & 0.315 & 0.741 & 4.03 & 0.92 \\
\hline $\mathrm{CC}$ will lead to a reduction in animal species & 0.587 & 0.553 & 4.03 & 0.88 \\
\hline $\begin{array}{l}\text { Migration from rural to urban areas will accelerate } \\
\text { in the future due to CC }\end{array}$ & 0.611 & 0.298 & 4.02 & 0.95 \\
\hline $\mathrm{CC}$ will cause a reduction in soil fertility & 0.787 & 0.267 & 3.99 & 1.01 \\
\hline $\begin{array}{l}\text { CC will cause an increase in human diseases and deaths } \\
\text { in the future }\end{array}$ & 0.421 & 0.576 & 3.97 & 0.94 \\
\hline $\mathrm{CC}$ will cause an increase in air temperature & 0.690 & 0.245 & 3.96 & 0.97 \\
\hline $\mathrm{CC}$ will lead to a reduction in forest areas & 0.820 & 0.194 & 3.84 & 1.01 \\
\hline Cronbach's alpha & 0.920 & 0.868 & - & - \\
\hline$\%$ Explained variance & 30.740 & 30.435 & - & - \\
\hline$\%$ Cumulative variance & 30.740 & 61.175 & - & - \\
\hline
\end{tabular}

Note: *1: Strongly Disagree, 2: Disagree, 3: Moderately Agree, 4: Agree, 5: Strongly Agree.

change, it is predicted that agricultural production costs will increase and the yield of agricultural products will decrease especially in regions with a temperate and semi-arid climate. Koç and Uzmay (2019) reported that climate change will lead to a $10-50 \%$ increase in costs for dairy farms by the year 2044 .

The present study pointed out that surveyed farmers believed that there is a correlation between climate change and weather events such as droughts, floods, and storms. They showed a very strong perception of the "Climate change will cause an increase in weather events such as droughts, floods, storms, etc." indicator. Extreme weather events occur in many regions, even in regions where climate change is relatively perceived less strongly. Therefore, it is difficult to attribute extreme weather events to a specific phenomenon resulting from climate change (Hirabayashi et al., 2013). But some scientific research express that any changing climate may be the reason for the changes in the frequency, intensity, spatial extent, duration, and timing of extremes, and can result in unprecedented weather events (Seneviratne et al., 2012). In parallel with our finding, farmers believed that 
extreme weather events will increase as a result of climate change in both developing economies (Hameso, 2017) and in developed economies (Lane et al., 2017).

Some important effects of climate change may involve plant diseases and damages. The possible effects of climate change are predicted three ways; (1) increased economic losses due to diseases, (2) changes in the efficiency of disease management strategies or (3) changes in the geographical distribution of plant diseases (Chakraborty et al., 2000). A research on the change in some abiotic conditions (temperature, $\mathrm{CO}^{2}$ and ozone concentration, precipitations, and drought) on the biology of pathogens and their ability to infect plants showed that changing abiotic conditions will affect the microclimate regulating plants and the susceptibility of plants to infection (Elad and Pertot, 2014). In parallel with the aforementioned research result, farmers believe that plant diseases and pests will increase due to climate change in Mersin. This finding is in line with Akhtar et al. (2018).

Farmers believe that soil erosion will accelerate and soil fertility will decrease due to climate change in the area under research. Farmers also believe that there will be reductions in both the amount of agricultural land and forest areas. Some scientific studies and projections about the effects of climate change on soil erosion, soil fertility and agricultural and forest areas support these views of farmers (Chmielewski et al., 2004; Nakicenovic et al., 2000).

According to FAO (2008), all the four dimensions of food security (food availability, food accessibility, food utilization, and food systems stability) will be adversely affected by climate change (FAO, 2008). In particular, water scarcity due to climate change will adversely affect agricultural production (Hanjra and Qureshi, 2010). In keeping with decreasing production, food availability and accessibility will be adversely affected. Climatic fluctuations as a result of climate change will also cause fluctuations in food production systems and this will adversely affect the food systems' stability (Schmidhuber and Tubiello, 2007). Farmers in the area under research area also agree that climate change will adversely affect food security. This research finding is supported by Polat and Dellal (2016) and Ahmed et al. (2013).

Today's biodiversity is an outcome of the evolutionary process; it is a natural event for some species to disappear and for some species to develop during this process. However, especially in the last century, the extinction of species has been the result of climate change that is caused by human influences and changing production and consumption patterns (Araújo and Rahbek, 2006). In addition, climate change leads to changes in the phonological structure of both flowering plants and pollinating insects, causing a mismatch between plants and pollinators. Then, these impacts cause both plants and pollinators to disappear (Bellard et al., 2012). According to the results of the present study, it can be said that farmers in the area under study believe that climate change will adversely affect both plants and animals' species and reduce biodiversity in the area under research. Similarly, Lorenzoni et al. (2007) reported that farmers perceived that climate change would harm other animal and plant species.

\subsection{Determinants of farmers' CC perceptions}

In this section, we run a regression analysis to determine factors affecting farmers' climate change perception. Independent variables and the results of the regression model were presented in Table 3. According to the results, two models were significant. Education, extension and cooperative variables were significant in the first model; experience and cooperative variables were significant in the second model.

In contrast to our expectation, the education level had a negative coefficient in the first model. This implies that more educated farmers perceived less important climate change indicators related to component 1 . This finding contradicted with Ndamani and Watanabe (2017). More educated farmers have the ability to better forecast and understand possible changes for the future compared to other colleagues. In the area under research, while the education levels of the farmers increased, the degree of importance they placed regarding the possible negative consequences of climate change de- 
Table 3 - Independent variables and the results of regression analysis.

\begin{tabular}{|c|c|c|c|c|c|c|c|}
\hline \multirow{2}{*}{$\begin{array}{l}\text { Independent } \\
\text { Variables }\end{array}$} & \multirow{2}{*}{ Definition } & \multirow{2}{*}{ Min. } & \multirow{2}{*}{ Max. } & \multirow{2}{*}{ Mean } & \multirow{2}{*}{$S D$} & \multicolumn{2}{|c|}{$\begin{array}{l}\text { Results of } \\
\text { regression model }\end{array}$} \\
\hline & & & & & & $C 1$ & $C 2$ \\
\hline Constant & & & & & & -0.342 & $0.539^{*}$ \\
\hline Age & Farmers' age in years & 21 & 87 & 48.62 & 11.18 & 0.012 & -0.026 \\
\hline Education & $\begin{array}{l}\text { Farmers' level of education; } \\
\text { 1: Elementary School, 2: High } \\
\text { School, 3: Undergraduate, 4: } \\
\text { Postgraduate }\end{array}$ & 1 & 4 & 1.6 & 0.82 & $-0.236^{* *}$ & 0.117 \\
\hline Family size & Number of members & 1 & 9 & 4.3 & 1.33 & 0.041 & -0.014 \\
\hline Experience & $\begin{array}{l}\text { Farmers' agricultural experience } \\
\text { in years }\end{array}$ & 1 & 75 & 26.48 & 14.83 & -0.008 & $0.018^{* *}$ \\
\hline Off-farm income & $\begin{array}{l}\text { If farmers had a source of off- } \\
\text { farm income } 1 \text {; } \\
\text { other } 0\end{array}$ & 0 & 1 & 0.43 & 0.5 & 0.129 & -0.063 \\
\hline Record-keeping & $\begin{array}{l}\text { If farmers kept physical } \\
\text { and financial records of the } \\
\text { production process } 1 \text {; other } 0\end{array}$ & 0 & 1 & 0.42 & 0.49 & -0.138 & -0.024 \\
\hline Extension & $\begin{array}{l}\text { If farmers were supported by } \\
\text { extension service } 1 \text {; other } 0\end{array}$ & 0 & 1 & 0.54 & 0.5 & 0.101 & $0.559 *$ \\
\hline Cooperative & $\begin{array}{l}\text { If farmers were a partner of an } \\
\text { agricultural cooperative } 1 \text {; other } 0\end{array}$ & 0 & 1 & 0.33 & 0.47 & $0.278^{* *}$ & $-0.314 * *$ \\
\hline Soil test & $\begin{array}{l}\text { If the farmers had a soil test } 1 \text {; } \\
\text { other } 0\end{array}$ & 0 & 1 & 0.31 & 0.46 & 0.013 & -0.129 \\
\hline Farmland & Total farmland as ha & 0.1 & 624 & 7.55 & 40.19 & 0.002 & -0.001 \\
\hline Adjusted R Square & & & & & & $0.074 * *$ & $0.054^{* *}$ \\
\hline
\end{tabular}

Note: Variables and models significant at $* p<0.10,{ }^{* *} p<0.05,{ }^{* * *} p<0.01$.

Table 4 - Farmers' climate change perceptions in terms of education (Component 1).

\begin{tabular}{|l|r|r|c|}
\hline Education & \multicolumn{1}{|c|}{$n$} & Mean $^{*}$ & \multicolumn{1}{c|}{$S D^{*}$} \\
\hline Elementary School & 150 & 4.08 & 0.76 \\
\hline High School & 56 & 3.99 & 0.68 \\
\hline Undergraduate & 41 & 3.83 & 0.66 \\
\hline Postgraduate & 4 & 3.72 & 0.33 \\
\hline Total & 251 & 3.91 & 0.61 \\
\hline
\end{tabular}

Note: *1: Strongly Disagree, 2: Disagree, 3: Moderately Agree, 4: Agree, 5: Strongly Agree. creased (Table 4). This may be the consequence of the prediction of more educated farmers that the harmful effects of climate change can be mitigated by developing technology and by improving production and consumption systems in accordance with nature.

Another significant variable was cooperative which had positive coefficient in the first model. Public and private cooperation can play a significant role in providing farmers with the necessary information, education and technologies (Alrusheidat et al., 206). This stated that farmers who were cooperative partners perceived more important climate change indicators related to component 1 . According to the results of the second model, the variables of farmers' cooperative partnership had significant effects on the per- 
Table 5 - Farmers' climate change perceptions in terms of cooperative partnerships.

\begin{tabular}{|l|c|c|c|c|c|}
\hline \multirow{2}{*}{ Cooperative Partnerships } & \multirow{2}{*}{$n$} & \multicolumn{2}{|c|}{ Component 1 } & \multicolumn{2}{c|}{ Component 2 } \\
\cline { 3 - 6 } & & Mean* & $S D^{*}$ & Mean* & $S D^{*}$ \\
\hline Yes & 83 & 4.10 & 0.63 & 4.15 & 0.64 \\
\hline No & 168 & 3.97 & 0.76 & 4.13 & 0.71 \\
\hline Total & 251 & 4.04 & 0.70 & 4.14 & 0.68 \\
\hline
\end{tabular}

Note: *1: Strongly Disagree, 2: Disagree, 3: Moderately Agree, 4: Agree, 5: Strongly Agree.

ceptions of farmers on climate change. Farmers, who are cooperative partners in the region under research, have higher perceptions about the items related to component 1 compared to other colleagues; their perception of items related to component 2 is lower (Table 5).

The positive coefficient for experience of farmers indicates that the more experienced they were, they more concern they expressed about climate change indicators related to component 2. The results are consistent with findings on farmers' climate change risk perceptions in India that showed that farming experience significantly affected farmers' climate change risk perception (Moghariya and Smardon, 2014). Obtaining information and enhancing knowledge about climate change from the extension services play an important role in improving farmers' climate change perception (Maddison, 2007). In accordance with the previous study, it was found that farmers' climate change perception was significantly affected by the availability of extension services in Mersin.

\section{Conclusions}

This research reflects on the fact that climate is changing in the area under study. In particular, the farmers' perception is critical in assisting policy makers in developing proactive precautions within the scope of the fight against climate change. The research results showed that the farmers had a favorable perception of climate change in Mersin. The study showed that farmers were highly aware of the economic and ecological risks that may arise due to climate change. They were worried about the negative effects of climate change on human and animal health. The result of the regression analysis indicated that some variables affecting farmers' perception. The results of the study showed that farmers have a positive attitude towards implementing measures to reduce the negative effects of climate change. Finally, it can be said that the study investigated the farmers' perception of climate change, but did not investigate whether farmers adopted appropriate practices to reduce climate change risks. Hence, further research should be conducted to find out whether farmers are likely to do so or if they already have.

\section{References}

Ahmad I., Tang D., Wang T., Wang M., Wagan B., 2015. Precipitation Trends over Time Using Mann-Kendall and Spearman's rho Tests in Swat River Basin, Pakistan. Advances in Meterorology. http://dx.doi.org/10.1155/2015/431860.

Ahmed M., Asif M., Sajad M., Khattak J. Z. K., Ijaz W., Fayyaz-ul-Hassan, W., et al. 2013. Could agriculturalsystem be adapted to climate change? A review. Australian Journal of Crop Science, 7(11): 16-42.

Alrusheidat J., Aljaafreh S., Abu Hammour W., 2016. Climate change adaptation and technology transfer: the path to disaster risk reduction in the arid and semi-arid zones. The case of Jordan. New Medit, 15(1), 2-6.

Akhtar R., Afroz R., Masud M.M., Rahman M., Khalid H., Duasa J.B., 2018. Farmers' perceptions, awareness, attitudes and adaption behaviour towards climate change. Journal of the Asia Pacific Economy, 23: 246-262.

Akyuz Y., Atis E., 2016. Türkiye'de iklim değişikliği tarım etkileşiminin iki yönüyle incelenmesi. Paper presented at the conference Uluslararası Katılıml 2. İklim Değişimi ve Tarım Etkileşimi Çalıştayı, Şanlıurfa, Turkey, pp. 120-127. 
Araújo M.B., Rahbek C., 2006. How does climate change affect biodiversity? Science, 313(5792): 1396-1397. doi: 10.1126/science.1131758.

Asfaw A., Simane B., Hassen A., Bantider A., 2018. Variability and time series trend analysis of rainfall and temperature in northcentral Ethiopia: A case study in Woleka sub-basin. Weather and Climate Extremes, 19: 29-41.

Aydogdu M., Yenigün K., 2016. Farmers' risk perception towards climate change: a case of the GAP-Şanlıurfa Region, Turkey. Sustainability, 8(8): 806. doi: https://doi.org/10.3390/su8080806.

Bellard C., Bertelsmeier C., Leadley P., Thuiller W., Courchamp F., 2012. Impacts of climate change on the future of biodiversity. Ecology Letters, 15(4): 365-377. doi: https://doi.org/10.1111/j.14610248.2011.01736.x.

Brunetti M., Buffoni L., Maugeri M., Nanni T., 2001. Trend of minimum and maximum daily temperature in Italy from 1865 to 1996 . Theoretical and Applied Climatology, 66: 49-60.

Bozoglu M., Baser U., Alhas Eroğlu N., Kilic Topuz B., 2019. Impacts of climate change on Turkish agriculture. Journal of International Environmental Application \& Science, 4(3): 97-103.

Buffoni L., Maugeri M., Nanni T., 1999. Precipitation in Italy from 1833 to 1996. Theoretical and Applied Climatology, 63: 33-40.

Chakraborty S., Tiedemann A.V., Teng P.S., 2000. Climate change: Potential impact on plant diseases. Environmental Pollution, 108(3): 317-326. doi: https://doi.org/10.1016/S0269-7491(99)00210-9.

Chmielewski F.M., Müller A., Bruns E., 2004. Climate changes and trends in phenology of fruit trees and field crops in Germany, 1961-2000. Agricultural and Forest Meteorology, 121(1): 69-78. doi: https://doi.org/10.1016/S0168-1923(03)00161-8.

Cronbach L.F., 1951. Coefficient alpha and the internal structure of tests. Psychometrika, 16(3): 297-334.

Daly-Hassen H., Annabi M., King-Okumu C., 2019. Social and private profitability of tree-based adaptation options to climate change in a dryland area of Tunisia. New Medit, 18(2): 89-105. http://dx.doi. org/10.30682/nm1902f.

Dellal I., McCarl B.A., Butt T., 2011. The economic assessment of climate change on Turkish agriculture. Journal of Environmental Protection and Ecology, 12(1): 376-385.

Dudu H., Çakmak E.H., 2018. Climate change and agriculture: An integrated approach to evaluate economy-wide effects for Turkey. Climate and Development, 10(3): 275-288. doi: 10.1080/17565529.2017.1372259.

Dumrul Y., Kilicaslan Z., 2017. Economic impacts of climate change on agriculture: Empirical evidence from ARDL approach for Turkey. Journal of Business Economics and Finance, 6(4): 336-347. doi: 10.17261/Pressacademia.2017.766.

Elad Y., Pertot I., 2014. Climate change impacts on plant pathogens and plant diseases. Journal of Crop Improvement, 28(1): 99-139. doi: $10.1080 / 15427528.2014 .865412$.

FAO, 2008. Climate change and food security: A framework document. Interdepartmental Working Group on Climate Change. Rome: FAO.

Fujihara Y., Tanaka K., Watanabe T., Naga-no T., Kojiri T., 2008. Assessing the impacts of climate change on the water resources of the Seyhan River Basin in Turkey: Use of dynamically downscaled data for hydrologic simulations. Journal of Hydrology, 353(1-2): 33-48.

Gujarati D.N., 2009. Basic econometrics. New Delhi: Tata McGraw-Hill Education.

Hanjra M.A., Qureshi M.E., 2010. Global water crisis and future food security in an era of climate change. Food Policy, 35(5): 365-377.

Hameso S., 2018. Farmers and policy-makers' perceptions of climate change in Ethiopia. Climate and Development, 10(4): 347-359.

Hatfield J.L., Boote K.J., Kimball B.A., Ziska L.H., Izaurralde R.C., Ort D., Thomson A.M., Wolfe D., 2011. Climate impacts on agriculture: Implications for crop production. Agronomy Journal, 103: 351-370.

Hirabayashi Y., Mahendran R., Koirala S., Konoshima L., Yamazaki D., Watanabe S., Kim H., Kanae S., 2013. Global flood risk under climate change. Nature Climate Change, 3: 816-821. doi: 10.1038/ nclimate1911.

Huang J., Sun S., Zhang J., 2013. Detection of trends in precipitation during 1960-2008 in Jiangxi province, southeast China. Theoretical and Applied Climatology, 114: 237-251.

IPCC (Intergovernmental Panel on Climate Change), 2007. Climate change 2007:The physical science basis. Contribution of Working Group I to the Fourth Assessment Report of the Intergovernmental Panel on Climate Change. Cambridge, UK/New York, NY, USA: Cambridge University Press, ch. 1, pp. 95-115.

IPCC (Intergovernmental Panel on Climate Change), 2012. Determinants of Risk: Exposure and Vulnerability. In: Managing the Risks of Extreme Events and Disasters to Advance Climate Change Adaptation. Cambridge, UK/New York, NY, USA: Cambridge University Press, ch. 2, pp. 65-109.

IPCC (Intergovernmental Panel on Climate Change), 2013. Detection and Attribution of Climate Chan- 
ge: from Global to Regional. In: Climate Change 2013. The Physical Science Basis. Contribution of Working Group I to the Fifth Assessment Report of the Intergovernmental Panel on Climate Change. Cambridge, UK/New York, NY, USA: Cambridge University Press, ch. 10, pp. 867-953.

IPCC (Intergovernmental Panel on Climate Change), 2014. Observed changes and their causes. In: Climate Change 2014 Synthesis Report. IPCC, Geneva, Switzerland, SPM 1, pp. 2-8.

Kadığlu M., (1997) Trends in surface air temperature data over Turkey. International Journal of Climatology, 17: 511-520.

Kanber R., Kapur B., Ünlü M., Tekin S., Koç L.D., 2008. İklim değişiminin tarımsal üretim sistemleri üzerine etkisinin değerlendirilmesine yönelik yeni bir yaklaşım ICCAP Projesi. In: TMMOB 2. Su Politikaları Kongresi, pp. 83-94.

Karakas G., Dogan H.G., 2018. The effect of climate change on apricot yield: A case of Malatya Province. In: Babacan H., Soldatovic T., Delebegovic Dzanıc N. (eds.), Academic Research in Social, Human and Administrative Sciences-I. Ankara: Gece Kitapliği, pp. 469-479.

Koç G., Uzmay A., 2019. The effect of climate change on the cost of dairy farms in Turkey; Case study of Thrace Region. New Medit, 18(3): 31-46.

Kousari M.R., Asadi Zarch M.A., 2011. Minimum, maximum, and mean annual tem-peratures, relative humidity, and precipitation trends in arid and semi-arid regions of Iran. Arabian Journal of Geosciences, 4(5-6): 907-914.

Lane D., Chatrchyan A., Tobin, D., Thorn, K., Allred S., Radhakrishna R., 2018. Climate change and agriculture in New York and Pennsylvania: Risk perceptions, vulnerability and adaptation among farmers. Renewable Agriculture and Food Systems, 33(3): 197-205. doi:10.1017/S1742170517000710.

Liang L.Q., Li L.J., Liu Q., 2010. Temporal variation of reference evapotranspiration during 1961-2005 in the Taoer River basin of Northeast China. Agricultural and Forest Meteorology, 150(2): 298-306.

Liu H.J., Li Y., Tanny J., Zhang R.H., Huang G.H., 2014. Quantitative estimation of climate change effects on potential evapotranspiration in Beijing during 1951-2010. Journal of Geographical Sciences, 24(1): 93-112.

Lorenzoni I., Nicholson-Cole S., Whitmarsh L., 2007. Barriers perceived to engaging with climate change among the UK public and their policy implications. Global Environmental Change, 17: 445-459.

Maddison D., 2007. The perception of and adaptation to climate change in Africa. Policy Research Wor- king Paper 4308. The World Bank Development Research Group, Sustainable Rural and Urban Development Team.

Marofi S., Soleymani S., Salarijazi M., Marofi H., 2012. Watershed-wide trend analysis of temperature characteristics in Karun-Dez watershed, southwestern Iran. Theoretical and Applied Climatology, 110: 311-320.

Meals D.W., Spooner J., Dressing S.A., Harcum J.B., 2011. Statistical analysis for monotonic trends. Tech Notes 6, November 2011. Developed for U.S. Environmental Protection Agency by Tetra Tech, Inc., Fairfax, VA.

Moghariya D. P., Smardon R. C., 2014. Rural perspectives of climate change: A study from Saurastra and Kutch of Western India. Public Understanding of Science, 23(6): 660-677.

Moreno J.I.L., Boike J., Sanchez-Lorenzoa A., Pomeroy J.W., 2016. Impact of climate warming on snow processes in Ny-Ålesund, a polar maritime site at Svalbard. Global and Planetary Change, 146: 10-21.

Muhlbauer A., Spichtınger P., Lohmann U., 2009. Application and Comparison of Robust Linear Regression Methods for Trend Estimation. American Meteorological Society, 48: 1961-1970. DOI: 10.1175/2009JAMC1851.1.

Nakicenovic N., Alcamo J., Grubler A., Riahi K., Roehrl R.A., Rogner H.-H., Victor N., 2000. Special report on emissions scenarios (SRES), a special report of Working Group III of the intergovernmental panel on climate change. Cambridge: Cambridge University Press.

Ndamani F., Watanabe, T., 2017. Determinants of farmers' climate risk perceptions in agriculture-A rural Ghana perspective. Water, 9(3): 210.

Niles M., Mueller N.D., 2016. Farmer perceptions of climate change: Associations with observed temperature and precipitation trends, irrigation, and climate beliefs. Global Environmental Change, 39: 133-142.

Novotny E.V., Stefan H.G., 2007. Stream flow in Minnesota: Indicator of climate change. Journal of Hydrology, 334: 319-333.

Öz F., 2019. The factors affecting paddy farmers' perception and adaptation strategies to climate change in Çorum Province, Turkey (unpublished master's thesis). Ondokuz May1s University, Graduate School of Sciences, Department of Agricultural Economics, Samsun, Turkey.

Partal T., Kahya E., 2006. Trend Analysis in Turkish Precipitation Data. Hydrological Processes, 20: 2011-2026.

Polat K., Dellal İ., 2016. Göksu Deltasında çeltik ye- 
tiştiriciliği yapan üreticilerin iklim değişikliği algısı ve iyi tarım uygulamaları yapmalarında etkili faktörlerin belirlenmesi. Tarım Ekonomisi Araştırmalarl Dergisi, 2: 46-54.

Porter J.R., Xie L., Challinor A.J., Cochrane K., Howden S.M., Iqbal M.M., Lobell D.B., Travasso M.I., 2014. Food security and food production systems. In: Field C.B., Barros V.R., Dokken D.J., Mach, K.J., Mastrandrea M.D., Bilir T.E., Chatterjee, M., Ebi K.L., Estrada Y.O., Genova R.C., Girma B., Kissel E.S., Levy A.N., MacCracken S., Mastrandrea P.R., White L.L. (eds.), Climate Change 2014: Impacts, Adaptation, and Vulnerability. Part A: Global and Sectoral Aspects. Contribution of Working Group II to the Fifth Assessment Report of the Intergovernmental Panel on Climate Change. Cambridge, UK/New York, NY, USA: Cambridge University Press, pp. 485-533.

Rodríguez-Díaz J.A., Topcu S., 2010. Sustaining Mediterranean irrigated agriculture under a changing climate. Outlook on Agriculture, 39(4): 269-275.

Schmidhuber J., Tubiello F.N., 2007. Global food security under climate change. Proceedings of the National Academy of Sciences, 104(50): 1970319708. doi: 10.1073/pnas.0701976104.

Sen P.K., 1968. Estimates of the regression coefficient based on Kendall's tau. Journal of American Statistical Association, 39: 1379-1389.

Seneviratne S.I., Nicholls N., Easterling D., Goodess C.M., Kanae S., Kossin J., Luo Y., Marengo J., McInnes K., Rahimi M., Reichstein M., Sorteberg A., Vera C., Zhang X., 2012. Changes in climate extremes and their impacts on the natural physical environment. In: Managing the Risks of Extreme Events and Disasters to Advance Climate Change Adaptation. A Special Report of Working Groups I and II of the Intergovernmental Panel on Climate Change (IPCC). Cambridge, UK/New York, NY, USA: Cambridge University Press, ch. 3, pp. 109-230.

Tayanç M., İm U., Doğruel M., Karaca M., 2009. Climate change in Turkey for the last half century. Climatic Change, 94: 483-502.

Topaloğlu F., Özfidaner M., 2012. Regional trends of precipitation in Turkey. Fresenius Environmetal Bulletin, 21: 2908-2915.

Trenberth K.E., 2011. Changes in precipitation with climate change. Climate Research, 47: 123-138.

Türkeş M., Sümer U.M., Kılıç G., 1995. Variations and trends in annual mean air temperaturesin Turkey with respect to climaticvariability. International Journal of Climatology, 15: 557-569.

Türkeş M., Sumer U.M., Demir Y., 2002. Re-evaluation of trends and changes in mean, maximum and minimum temperatures of Turkey for the period 1929-1999. International Journal of Climatology, 22: 947-977.

Tsujii H., Gültekin U., 2019. An econometric and agro-meteorological study on rain-fed wheat and barley in Turkey under climate change. In: Watanabe T., Kapur S., Aydın M., Kanber R., Akça E. (eds.), Climate Change Impacts on Basin Agro-ecosystems. Cham: Springer (The Anthropocene: Politik-Economics-Society-Science, vol. 18). 